\title{
Corrosión por cloruros del acero de refuerzo embebido en concreto con agregado grueso reciclado y materiales cementantes suplementarios
}

\section{Chloride corrosion of embedded reinforced steel on concrete elaborated from recycled coarse aggregates and supplementary cement materials}

\author{
Ramón Corral H. ${ }^{*}$, Susana Arredondo R.*, Jorge Almaral S.*, José Gómez S.** \\ * Universidad Autónoma de Sinaloa, Sinaloa. MÉXICO \\ ** Universidad Politécnica de Cataluña, Barcelona. ESPAÑA
}

Fecha de Recepción: 30/10/2012

Fecha de Aceptación: 30/01/2013

PAG 21 - 35

\begin{abstract}
Resumen
Como estrategias contributivas de sustentabilidad en la industria del concreto, en la actualidad se está investigando en mejorar la durabilidad de las estructuras de concreto reforzado, como así también en el reemplazo parcial o total de sus componentes por materiales reciclados. En el caso de las barras de acero, la corrosión se considerada el principal problema de durabilidad del concreto reforzado. En esta investigación, se utilizó agregado grueso de concreto reciclado y materiales cementantes suplementarios subproductos de procesos industriales tales como las cenizas volantes y el humo de sílice para la fabricación de concretos con características de sustentabilidad y para la evaluación de su comportamiento ante la exposición a cloruros. De los especímenes de prueba resultantes, se determinaron los parámetros de resistencia a compresión, resistividad eléctrica, resistencia a la transferencia de carga y resistencia a la penetración del ión cloruro, que especifican los mínimos de las propiedades exigibles a los concreto en acuerdo a normativa para garantizar su durabilidad ante la acción de los cloruros. De los resultados obtenidos, se concluye que el concreto fabricado con 100\% de agregado grueso reciclado y materiales cementantes suplementarios mejora su desempeño, en cuanto a resistencia y durabilidad al ser comparado con el concreto convencional.
\end{abstract}

Palabras Clave: Concreto reciclado, corrosión, resistividad eléctrica, espectroscopía de impedancia electroquímica, penetración de cloruros

\begin{abstract}
As a result of contributive and sustainable strategies on concrete industry, researches are presently being developed, which are focused on improving durability of reinforced concrete structures as well as partially or completely replacing their components by recycled materials. In the case of steel bars, corrosion is considered as the major durability menace to reinforced concrete. The present research employed coarse aggregate from recycled concrete and supplementary cement materials, which are byproducts of industrial processes, such as fly ashes and silica fume, for the elaboration of sustainable concretes and for the evaluation of their behavior faced to chlorides exposure. Compressive resistance, electric resistivity, loading transfer resistance and ion chloride permeability resistance are the parameters which were determined from the resulting test specimens, thus specifying the minimum required properties for concrete, in accordance with regulations that guarantee its durability faced to chloride actions. From results obtained it is concluded that concrete elaborated using a 100\% of recycled coarse aggregate and supplementary cement materials improves its behavior as far as resistance and durability are concerned, in comparison to conventional concrete.
\end{abstract}

Keywords: recycled concrete, corrosion, electric resistivity, electro-chemical impedance spectroscopy, chloride permeability

\section{Introduction}

As a result of the significant environmental impact caused by the concrete elaboration process and as contributive sustainability measures in this industry, improvements are presently being implemented to concrete durability, as well as the replacement of its components by alternative recycled materials. Among the most common alternative materials for concrete elaboration we find those partially replacing Portland cement (Supplementary Cement Materials [SCM]), such as silica fume (SF), flying ashes (FA) and blast furnace slag. As far as aggregates are concerned Recycled Concrete Aggregates (RCA) are being used to replace natural aggregates.

${ }^{1}$ Autor de correspondencia / Corresponding author:

E-mail:rmn1779@gmail.com 
In a regular concrete mix, aggregates correspond to approximately a $70 \%$ of its volume. Therefore, great amounts of crushed stone, gravel and sand are extracted, processed and transported thus generating important economical and environmental costs. Recycling concrete from demolition works and construction's waste materials have been studied since the 50`s, however only ten years ago the number of researches have been increased on this subject (Ajdukiewicz and Kliszczewicz, 2002; Chen et al., 2003; Katz, 2003; Poon et al., 2004; Topçu and Sengel, 2004; Tu et al., 2006; Martínez and Mendoza, 2006; Rahal, 2007; Casuccio et al., 2008; Padmini et al., 2009). Nevertheless, most of them have focused their studies on RCA's physic-mechanical properties and concrete made from Recycled Aggregate Concrete [RAC], not considering so far the RCA corrosion effect of embedded reinforced steel on RAC exposed to adverse environmental conditions, such as marine environment.

Nowadays, the most important pathology suffered by reinforced concrete structures is corrosion damage, which is caused by chloride penetration into concrete and, also concrete carbonation at a lesser extent. Corrosion, which limits duration of reinforced concrete structures, has even reported economical losses of about 276 billion dollars a year (Federal Highway Administration, 2002).

On the other hand, concretes with SCM addition are reporting a proper acceptance for this purpose (Ann et al., 2008; González and Martínex, 2008; Kou and Poon, 2008; Berndt, 2009; Corinaldesi and Moriconi, 2009), highlighting the positive impact of SCM on resistance and durability behaviors, as well as the environmental benefits they provide.

Concretes elaborated from recycled materials (SCM or RCA) have different micro-structure. In the case of RCA concrete, it has greater porosity than conventional concretes (Gómez, 2002; Poon et al., 2004; Tam et al., 2005; Etxeberría et al., 2007). On the other hand, it has been demonstrated that concrete electric resistivity is associated with the microstructure of cement matrix (pores distribution) and with the corrosion rate of reinforced steel (Tumidajski et al., 1996; Tumidajski, 2005; Polder et al., 2000). Therefore, the electric resistivity is used as a parameter to evaluate concrete durability. The purpose of this research is to analyze electric resistivity and the electro-chemical response of reinforced concrete to obtain the RCA and SCM effects on the reinforcement corrosion beginning and rate induced by the accelerated chloride penetration. On reinforced concrete specimens tests of Electrochemical Impedance Spectroscopy (EIS) were carried out in order to determine the electric resistivity and loading transfer resistance, so as to evaluate the corrosion process. Additional parameters were employed by characterizing the mechanical behavior and the ion chloride penetration resistance by means of compressive resistance tests and chloride rapid chloride permeability tests, respectively. 


\section{Experimental methodology}

Four specimen series were elaborated using water-cement material of 0.48 ratios: a) reference series elaborated from natural aggregate (NA) and $100 \%$ of Portland Cement (PC) Type I in accordance with ASTM C150; b) series made up from coarse aggregate and $100 \%$ PC; c) series elaborated from coarse RCA and 30\% FA as partial replacement of PC and; at last d) series fabricated from coarse RCA and $10 \%$ SF as partial replacement of $P C$. The characteristics and proportions of mixes under study are presented on Table 1. Water amount reported on Table 1 corresponds to the actual amount of water because the recycled aggregates were saturated during ten minutes before mixing took place.

Tabla 1. Características y proporciones de las mezclas de estudio (Relativo a $1 \mathrm{~m} 3$ de concreto)

Table1. Characteristics and proportions of mixes under study (considering $1 \mathrm{~m}^{3}$ concrete)

\begin{tabular}{|c|c|c|c|c|}
\hline \multirow{3}{*}{$\begin{array}{l}\text { Materiales/Materials } \\
(\mathrm{Kg})\end{array}$} & \multicolumn{4}{|c|}{ Identificación de las mezclas/Mixes Identification $(\mathrm{a} / \mathrm{mc}=0.48)$} \\
\hline & \multirow{2}{*}{$\begin{array}{c}\text { Agregado grueso y fino } \\
\text { natural/Coarse and fine } \\
\text { natural aggregate }\end{array}$} & \multicolumn{3}{|c|}{$\begin{array}{c}\text { Agregado grueso reciclado, arena natural y SCM/Recycled coarse } \\
\text { aggregate, natural sand and SCM }\end{array}$} \\
\hline & & RCA $100 \%$ PC & RCA $30 \%$ FA & RCA $10 \%$ SF \\
\hline Agua/Water* & 213.31 & 213.31 & 213.31 & 213.31 \\
\hline Grava/Gravel** & 994.55 & 870.58 & 870.58 & 870.58 \\
\hline Arena/Sand & 766.17 & 915.35 & 915.35 & 915.35 \\
\hline Cemento/Cement & 444.44 & 444.44 & 311.11 & 400.00 \\
\hline SCM & 0.000 & 0.000 & 133.33 & 44.44 \\
\hline
\end{tabular}

\section{Materials}

RCA comes from the process of crushing concrete specimens elaborated with: natural aggregates, $P C$ type I, water/cement ratio of 0.50 (compression resistance at $30 \mathrm{MPa}$ ) and they were cured during a period of 28 days at relative temperature and humidity $(\mathrm{RH})$ of $23 \pm 2{ }^{\circ} \mathrm{C}$ and $98 \pm 1 \%$, respectively. Natural aggregates come from quarry crushed stones (coarse) and river sand (fine). All the employed aggregates reported a proper grain size distribution, in accordance with limits established by ASTM C33 (Figure 1 and Figure 2) and, some of their physical properties are shown on Table 2. Natural aggregates to be used for elaborating the source concrete and concretes under study come from the same excavation site.

Low-calcium Mexican FA, Class F was employed as SCM in accordance with ASTM C618 regulation and also American SF, which meet the requirements established by ASTM C1240 standard. Table 3 shows the physical-chemical properties of such materials. 


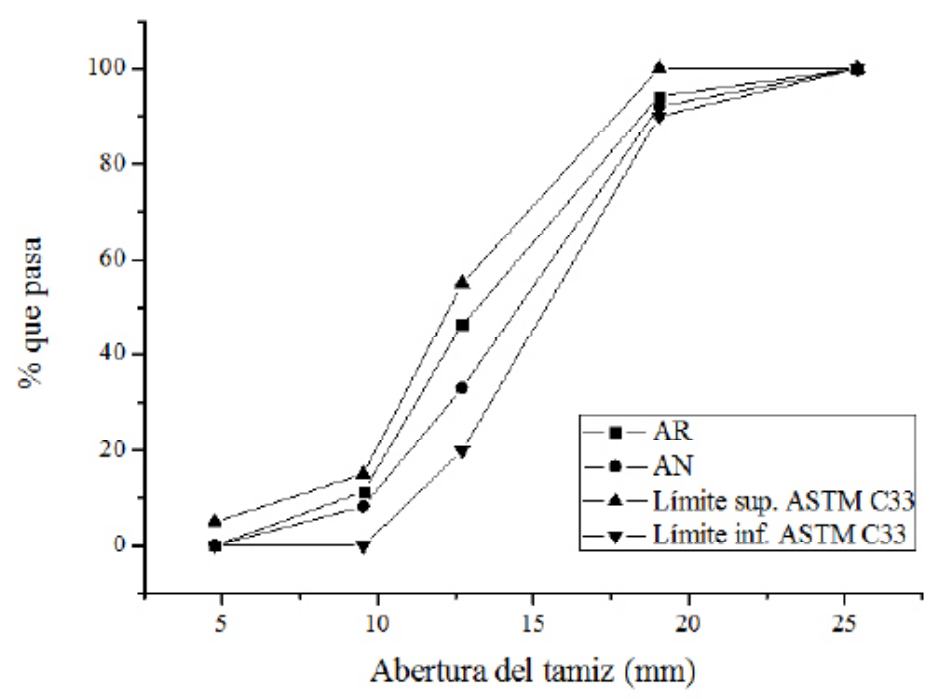

Figura 1. Graduación granulométrica de los agregados gruesos

Figure 1. Grain size distribution of coarse aggregates

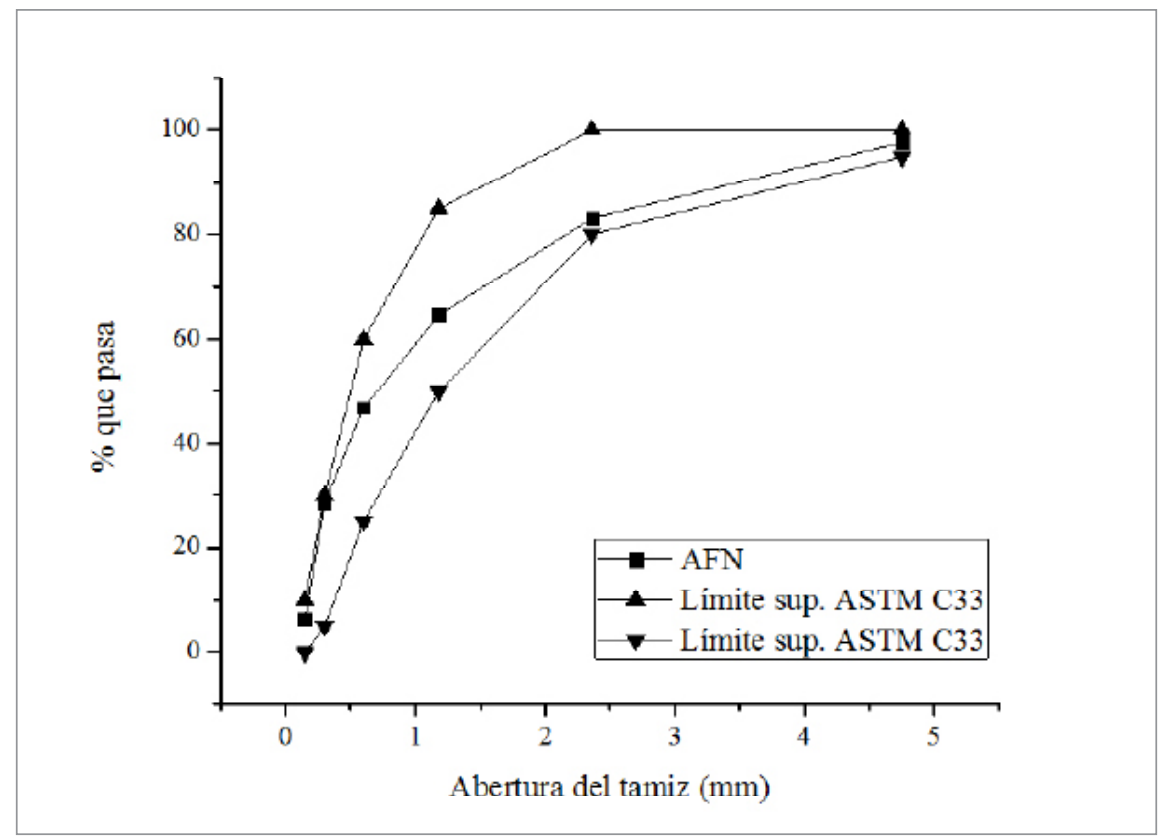

Figura 2. Graduación granulométrica del agregado fino

Figure 2. Grain size distribution of fine aggregate

Tabla 2. Propiedades físicas de los agregados

Table 2. Aggregates physical properties

\begin{tabular}{|c|c|c|c|c||}
\hline $\begin{array}{c}\text { Tipo de agregado } \\
\text { Type of aggregate }\end{array}$ & $\begin{array}{c}\text { Densidad relativa } \\
\text { Relative Density } \\
\left(\mathbf{g} / \mathbf{c m}^{\mathbf{3}}\right)\end{array}$ & $\begin{array}{c}\text { Absorción } \\
\text { Absorption } \\
(\mathbf{\%})\end{array}$ & $\begin{array}{c}\text { Módulo de finura } \\
\text { Fineness modulus } \\
(\mathbf{\%})\end{array}$ & $\begin{array}{c}\text { Tamaño máximo } \\
\text { Maximum size } \\
\text { (mm) }\end{array}$ \\
\hline $\begin{array}{c}\text { Grueso reciclado/ } \\
\text { Recycled coarse }\end{array}$ & 2.19 & 6.55 & - & 19 \\
\hline $\begin{array}{c}\text { Grueso Natural/ } \\
\text { Natural coarse }\end{array}$ & 2.50 & 0.44 & - & 19 \\
\hline $\begin{array}{c}\text { Fino Natural/ } \\
\text { Natural fine }\end{array}$ & 2.43 & 4.08 & 2.73 & 4.76 \\
\hline
\end{tabular}


Tabla 3. Propiedades físico-químicas de los materiales cementantes

Table 3. Physical-chemical properties of cement materials

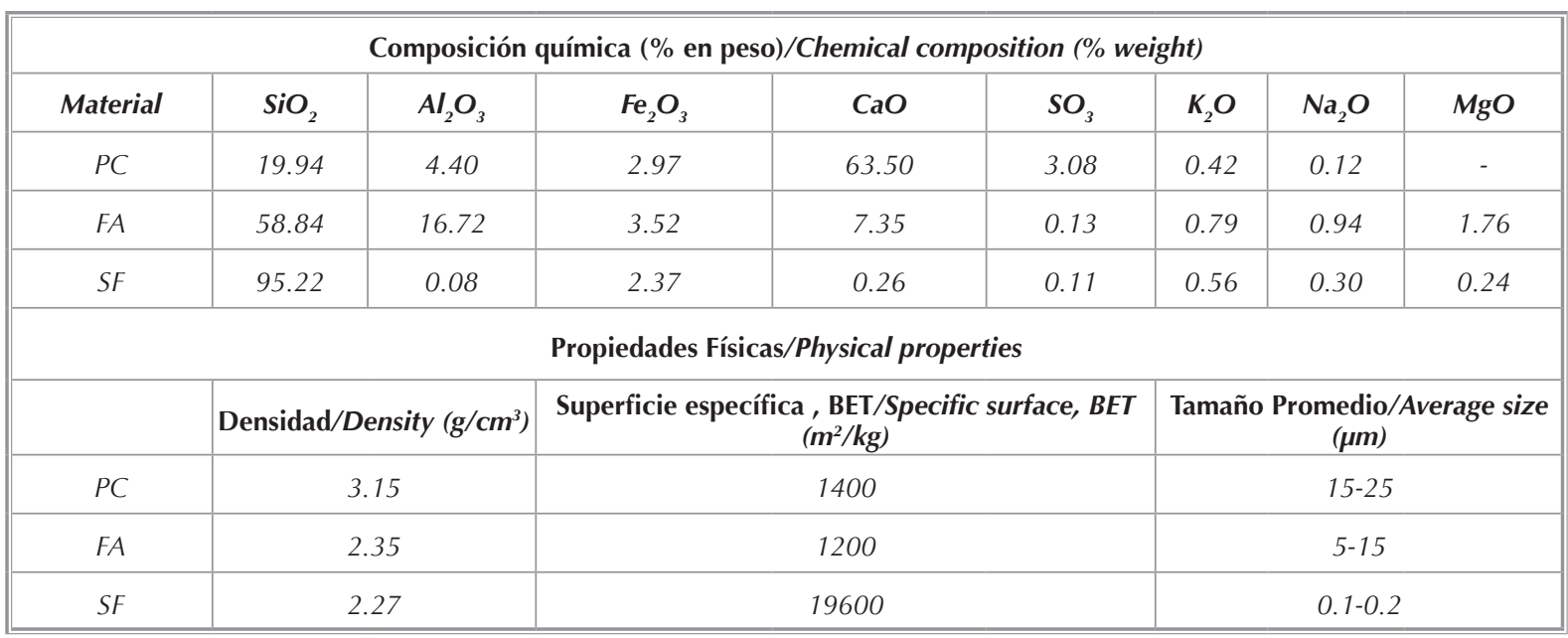

Compressive resistance and total porosity

The assessment of compressive resistance on each series was carried out by using nine cylindrical specimens ( $h=30$ $\mathrm{cm}, \Phi=15 \mathrm{~cm})$; by following the standard procedure ASTM C39. Three cylindrical specimens of each mix were tested under compression at 28, 90 and 180 days of curing process. The employed samples were cured by a chamber at temperatures of $23 \pm 2{ }^{\circ} \mathrm{C}$ and $98 \pm 1 \%$ of $\mathrm{RH}$. After 90 curing days, the total porosity of concretes under study was determined by following the standard procedure ASTM C642. For this purpose, three specimens were prepared, each having 5 $\mathrm{cm}$ thickness and $10 \mathrm{~cm}$ diameter for each mixture under study.

\section{Electro-chemical Impedance Spectroscopy}

So as to evaluate the electrical resistivity and the loading transfer resistance of steel-concrete systems under study, three cylindrical specimens were elaborated $(L=30 \mathrm{~cm}$, $\Phi=15 \mathrm{~cm}$ ) for each mix identified on Table 1. Each specimen was supplied with two carbon steel embedded bars UNS G10180 of $\Phi=0.95 \mathrm{~cm}$, having an exposed area of $64 \mathrm{~cm}^{2}$ and they were placed at $4.5 \mathrm{~cm}$ from the outside. Steel bars were paint-peeled and cleaned before installing. After the 28 days of curing process was over, the specimens were partially submerged (at $20 \mathrm{~cm}$ depth) in a liquid solution of $\mathrm{NaCi} 3.5 \%$. Submersion period took six months, since then the chloride penetration was accelerated by subjecting the specimens to humectation and drying cycles (the specimens were submerged for three days and then they were dried in a forced ventilation chamber at $40^{\circ} \mathrm{C}$ during four days). The electrolytic variation (Re), corresponding to concrete resistivity $(\rho)$, as well as loading transfer resistance variation (Rct) corresponding to corrosion current density $\left(i_{\text {corr }}\right)$ of the reinforcement were monthly measured under submersion conditions. 
The evaluation of parameters (Re and Rct) was developed by means of EIS in a potentiostat/galvanostat/zero resistance ammeter manufactured by ACM Instruments. Test parameters corresponded to a $10 \mathrm{mV}$ amplitude potential in order to maintain a linearity of the system, at a frequency range from $1 \mathrm{MHz}$ to 10 $\mathrm{kHz}$. The experimental test layout is shown on Figure 3.

The EIS results were represented by means of Nyquist diagrams [Figure 4 a)] and an equivalent electric circuit (EEC) of Randles type - as the one shown on Figure 4b) - was used to accurately determine the intersection value at low frequencies of the curve with the actual impedance axis, so that Rct could be calculated.

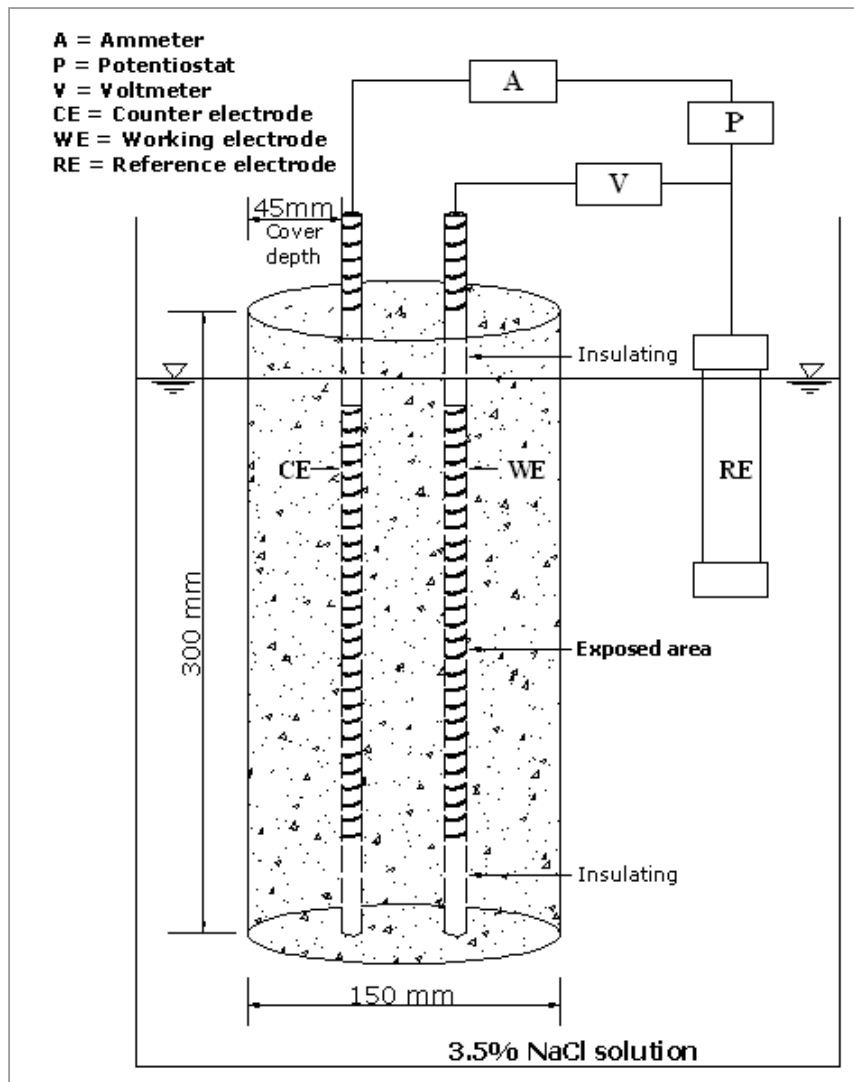

Figura 3. Arreglo experimental para los ensayos de EIS

Figure 3. Experimental set up for EIS test

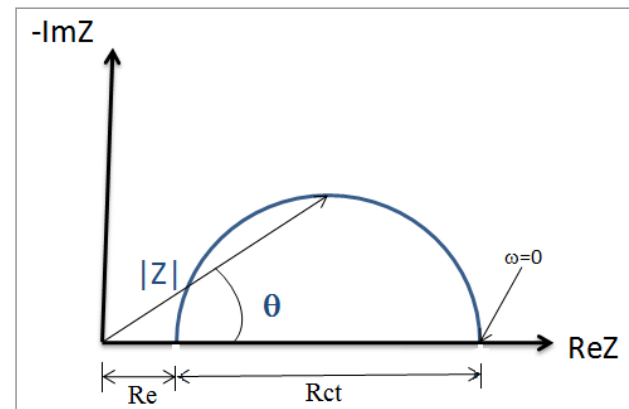

a)

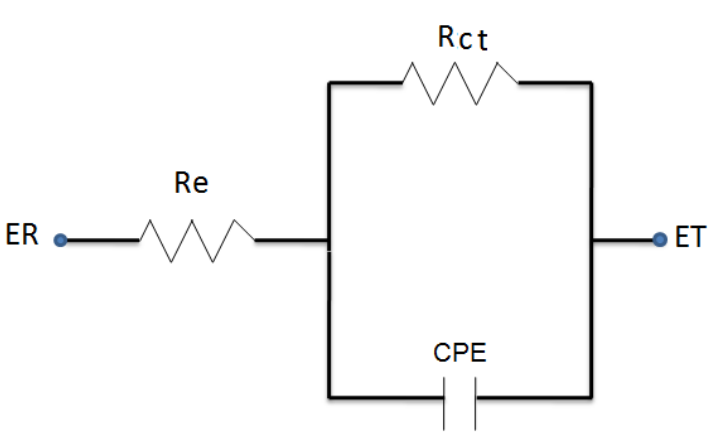

b)

Figura 4. a) Diagrama de Nyquist ideal, b) EEC usado para determinar Rct

Figure 4. a) Ideal Nyquist diagram, b) EEC used to determine Rct 
The resulting Rct and the Re, obtained from the intersection at high frequencies of Nyquist diagrams with the actual impedance axis, were used to determine $i_{\text {corr }}$ and the concrete electric resistivity ( $\rho)$, respectively. By using Equation 1(Stern and Geary, 1957) $i_{\text {corr }}$ was calculated, where B is Tafel constant at a recommended value of $0.052 \mathrm{~V}$ (Dhir et al., 1993; González et al., 1996; Gowers and Milard, 1993; Mangat and Molloy, 1992) for passive reinforcement steel corrosion and; $0.026 \mathrm{~V}$ for active corrosion. $\rho$ was determined by means of Equation 2, where $C_{c}$ is a cell constant, which depends on the geometry of the conductive body (Torrents et al., 1998).

$i_{\text {corr }}=\frac{B}{R c t}$

$\operatorname{Re}=\rho \cdot C_{c}$
(1)

(2)

Where: $C_{c}$ is a cell constant $(58.47 \mathrm{~cm}) ; L$ is the submerged length of reinforced concrete specimen during the test (20 $\mathrm{cm})$; $D$ is the diameter of concrete specimen $(15 \mathrm{~cm}) ; d$ is the diameter of reinforced steel $(0.95 \mathrm{~cm})$ and; $z$ is the distance between the concrete specimen core and the reinforcement bar center $(0.05 \mathrm{~cm})$.

The cell constant $C_{c}$ was analytically determined (Equation 3) by applying heat conductive principles throughout the elements (Sunderland and Johnson, 1964). Laplace Equation was solved by considering the temperature of steel body (reinforcement) $T_{1}$, and the temperature of concrete Body $T_{2}$ as boundary limits; where $T_{1}=T_{2}=$ constant.

$$
C_{c}=\left(\frac{2 \pi L}{\cosh ^{-1}\left(\frac{D^{2}+d^{2}-4 z^{2}}{2 D d}\right)}\right)
$$

\section{Ion chloride penetration resistance}

The so called Rapid Chloride Permeability Test (RCPT) was performed in accordance with ASTM C1202. The tests were carried out on specimens at 90 curing days $(h=5 \mathrm{~cm}$, $\Phi=10 \mathrm{~cm})$, which were extracted from the concrete cylinders cores $(h=20 \mathrm{~cm})$. After 24 hours from their elaboration, the specimens were placed between two acrylic cells connected to a potentiostat. One of the specimens was filled up with a $\mathrm{NaOH}$ liquid solution at $0.3 \mathrm{~N}$ and; the other specimen with a liquid solution of $3 \% \mathrm{NaCl}$. Cells were connected to the power supply source, where the electrode of the $\mathrm{NaCl}$ cell acted as a cathode and, the electrode filled up with $\mathrm{NaOH}$ worked as an anode. A constant power supply of $60 \mathrm{~V}$ was applied during six hours and, the power was registered every half an hour. The test layout is shown on Figure 5. 


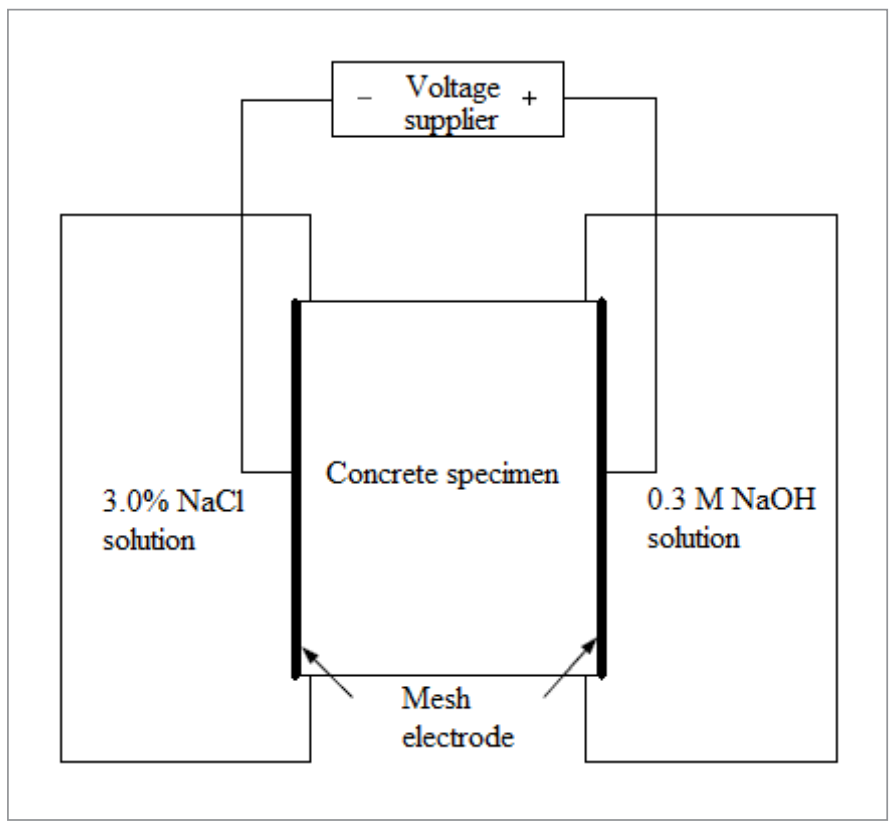

Figura 5. Configuración experimental para la RCPT

Figure 5. Experimental configuration to RCPT

Total load (Q) passing through the specimen was calculated by means of Equation 4, in accordance with the trapezoid rule.

$Q=900 x\left(I_{0}+2 I_{30}+2 I_{60}+\ldots .+2 I_{330}+2 I_{360}\right)$

Where: $Q$ is expressed in Coulombs; and "In" corresponds to power supply (A); " $a$ " corresponds to " $n$ " minutes after the power is applied. Since $Q$ is associated with the concrete resistance faced to ion chloride penetration, it was determined by means of a qualitative criterion proposed by ASTM C1202, as shown on Table 4.

Tabla 4. Penetrabilidad al ión cloruro basada en la carga pasada

Table 4. Ion chloride penetration based on passing load

\begin{tabular}{|c|c|}
\hline $\begin{array}{c}\text { Carga Pasada/Passing load } \\
\text { (C) }\end{array}$ & $\begin{array}{c}\text { Penetrabilidad al ión cloruro/Ion chloride } \\
\text { penetration }\end{array}$ \\
\hline$>4000$ & Alta/High \\
\hline $2000-4000$ & Moderada/Moderate \\
\hline $1000-2000$ & Baja/Low \\
\hline $100-1000$ & Muy baja/Very low \\
\hline$<100$ & Insignificante/Insignificant \\
\hline
\end{tabular}

\section{Results and discussion}

\section{Compressive resistance and total porosity}

The obtained percentages of total porosity for variables NA $100 \%$ PC; RCA $100 \%$ PC, RCA $30 \%$ FA and RCA $10 \%$ SF were 22, 26, 23 y 17, respectively. In accordance with such results, the use of RAC significantly incremented the concrete porosity, while the use of SCM reduced it. 
This behavior was also observed by other researchers (Corinaldesi and Moriconi, 2009; Gómez, 2002).

The compressive resistance of four variables under study is presented on Table 5, which validates the RCA and SCM effects on the evolution of compressive resistance. The mix used to evaluate RCA effect on compressive resistance (RCA 100\% PC) developed resistances of 26, 28 and $32 \mathrm{MPa}$ at 28, 90 and 180 curing days, respectively. These values represent resistance losses of 13, 15 and $10 \%$, respectively, compared to the control variable; which is in line with other researchers (Katz, 2003; Topçu and Sengel, 2004; Martínez and Mendoza, 2006; Rahal, 2007; Casuccio et al., 2008). The variable RCA $10 \%$ SF reported the highest compressive resistance value at 28, 90 and 180 curing days (37, 41 and $43 \mathrm{MPa}$, respectively), which indicates that the use of $10 \%$ SF is translated into a resistance gain of 45,44 and $35 \%$ higher than the variable RCA $100 \%$ PC. Furthermore, these gains are higher than the ones obtained by the conventional concrete variable (NA $100 \%$ PC). As far as the use of FA is concerned, the mix RCA 30\% FA delivered the lowest resistances (17, 21 and 27 Mpa), yielding losses of 32, 25 and $15 \%$ in comparison to the variable RCA $100 \%$ PC (28, 90 and 180 curing days, respectively). Although the use of RCA and FA leads to compressive resistance losses, the mixes containing such materials exceed resistances by 20 MPa at 90 days.

Tabla 5. Resistencia a la compresión de los concretos investigados Table5. Compressive resistance of concretes under study

\begin{tabular}{|c|c|c|c|}
\hline \multirow{2}{*}{ Mezcla/Mix } & \multicolumn{3}{|c|}{ Resistencia a compresión/Compressive resistance (MPa) } \\
\cline { 2 - 4 } & $\mathbf{2 8}$ días/28 days & $\mathbf{9 0}$ días/90 days & $\mathbf{1 8 0}$ días/180 days \\
\hline NA 100\% PC & 29.25 & 33.16 & 35.35 \\
\hline RCA 100\% PC & 25.57 & 28.35 & 31.83 \\
\hline RCA 30\% FA & 17.39 & 21.26 & 27.06 \\
\hline RCA 10\% SF & 37.08 & 40.82 & 42.97 \\
\hline \hline
\end{tabular}

\section{Electro-chemical Impedance Spectroscopy}

Dielectric and electro-chemical properties of concretesteel systems at 3, 6, 9 and 12 months of exposure are represented by Nyquist diagrams on Figures $6 a$ and $6 d$. They show the influence of RCA on Re (curve intersection at high frequencies) and also on the Rct (semi-circle diameter or arc). The system RCA 100\% PC delivers the lowest Re values (1.22 a $\left.3.30 \times 10^{2} \mathrm{k} \Omega-\mathrm{cm}^{2}\right)$, which indicates that the use of $100 \% \mathrm{RCA}$ increases the electric conductivity of concrete. However, when replacing cement by $F A$ and $S F$, the concrete Re significantly increases (decreasing the electric conductivity), specially when using SF (from $4.16 \times 10^{2}$ to $1.48 \times 10^{3} \mathrm{k} \Omega-\mathrm{cm}^{2}$ ). As far as Rct is concerned, it shows a similar behavior; thus being the RCA $10 \%$ the one that reports maximum Rct values during the exposure period (from $6.25 \times 10^{2}$ to $6.79 \times 10^{3} \mathrm{k} \Omega-\mathrm{cm}^{2}$, while the RCA $100 \%$ PC reported minimum Rct values $\left(8.64 \times 10^{2}\right.$ to $\left.7.98 \times 10^{1} \mathrm{k} \Omega-\mathrm{cm}^{2}\right)$. 

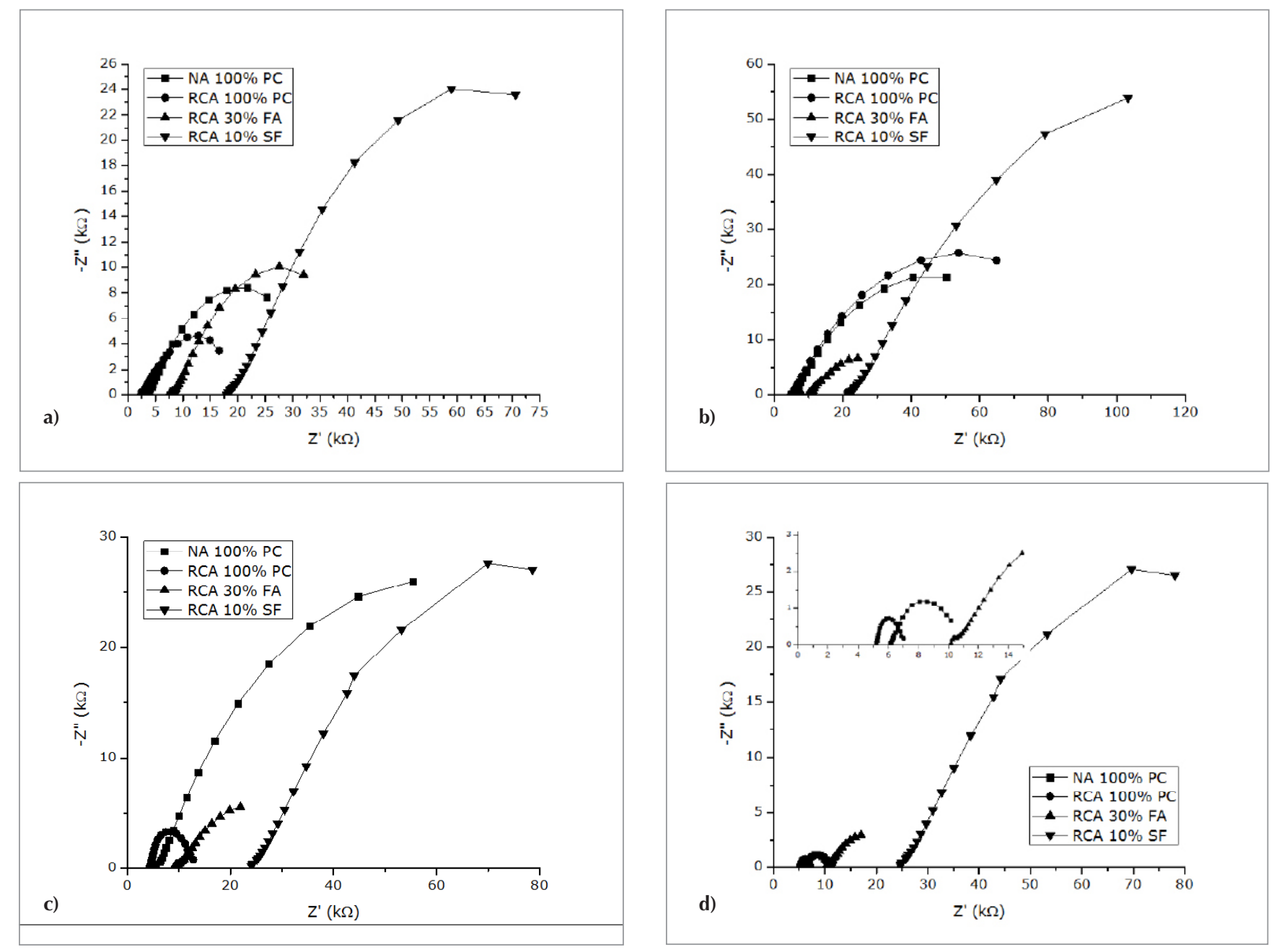

Figura 6. Diagramas de Nyquist para los sistemas concreto-acero a diferentes edades de exposición: a) 3 meses, b) 6 meses, c) 9 meses y d) 12 meses Figure 6. Nyquist diagram for concrete-steel systems to different exposed ages: a) 3 months, b) 6 months, c) 9 months and d) 12 months

The $\rho$ as function of exposure period is shown on Figure 7, proving that the use of $100 \%$ RCA increases concrete electric conductivity, which is attributed to the porosity increase reported by $R C A$ concretes, that facilitate the ionic conductivity. The $\rho$ of SCM-free systems (NA 100\% PC and RCA 100\% PC) do not exceed the $10 \mathrm{k} \Omega-\mathrm{cm}$ threshold (Andrade and Alonso, 1996). Regarding SCM systems, they have a significant and positive effect on the $\rho$ of concrete; the $\rho$ of system RCA $30 \%$ FA doubles the value of SCM systems; while $\rho$ of RCA $10 \%$ SF system is four times higher. Similar results were found by Fajardo et al. (2009).

Figure 7 shows that during the first three months of testing process, the $\rho$ of SCM systems is quickly increased, which is further on stabilized. The latter can be explained by assuming that reactions are close to a balance after an exposure period of approximately 90 days. The increasing $\rho$ of SCM systems is attributed to the decrease of pore system, which takes place due to the SCH formation and because of the reduction of $\mathrm{CH}$ formation caused by the pozzolanic reaction between them and the $\mathrm{SiO}_{2}$ contained by SCMs. Table 3 shows that SF is about 100 times finer than cement and FA and it delivers a higher amount of $\mathrm{SiO}_{2}$. 


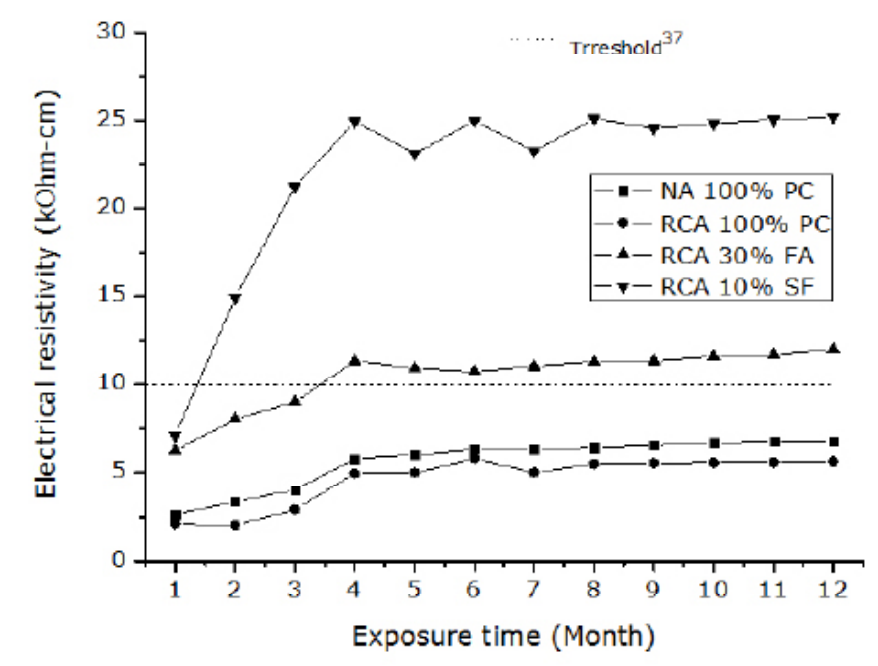

Figura 7. Evolución de la resistividad eléctrica en función del tiempo de exposición

Figure 7. Evolution of electric resistivity as a function of exposure time

The $i_{\text {corr }}$ results determined from Rct values are presented on Figure 8 , thus enabling us to confirm the corrosion resistance of steel-concrete systems in this research. In general, during the fourth testing month, an inflection point is localized between two corrosion states at different activity level. This sectorization is explained because from this point further the hydration-pozzolanic reactions of the cement and the SCM reached a balance state and, therefore their speed is also stabilized. Besides, it is observed that the system showing highest corrosion resistance is RCA $10 \%$ SF, in spite of the fact that its corrosion activity was the highest during the first month; then it significantly decreases as months went by until reaching a minimum corrosion rate $\left(0.004 \mu \mathrm{A} / \mathrm{cm}^{2}\right)$ in the sixth testing month, with an average of $0.016 \mu \mathrm{A} / \mathrm{cm}^{2}$ for the whole test period. It is also observed that the use of SF significantly delays the beginning of corrosion because it keeps under a passive state until month twelve. On the other hand, the system RCA 100\% PC reported the maximum corrosion levels (from 0.044 to $0.060 \mu \mathrm{A} / \mathrm{cm}^{2}$ ) until the third month and; although between the fourth and eighth month its corrosion activity substantially decreases, it registers the highest $i_{\text {corr }}$ average $\left(0.102 \mu \mathrm{A} / \mathrm{cm}^{2}\right)$ for the whole period. Therefore, this system is classified as the one with lowest corrosion resistance and discloses the negative effect of RCAs on reinforcement corrosion susceptibility, because its corrosion activity turned from passive to active state during the eighth month (before than any other system). The system RCA $30 \%$ FA reports low corrosion levels until the second testing month (from 0.022 to $0.037 \mu \mathrm{A} / \mathrm{cm} 2$ ), maintaining its activity at that level during the consecutive months; its average icorr was $0.026 \mu \mathrm{A} / \mathrm{cm} 2$, and it can be observed that the use of FA delays depassivation time of the reinforcement. 


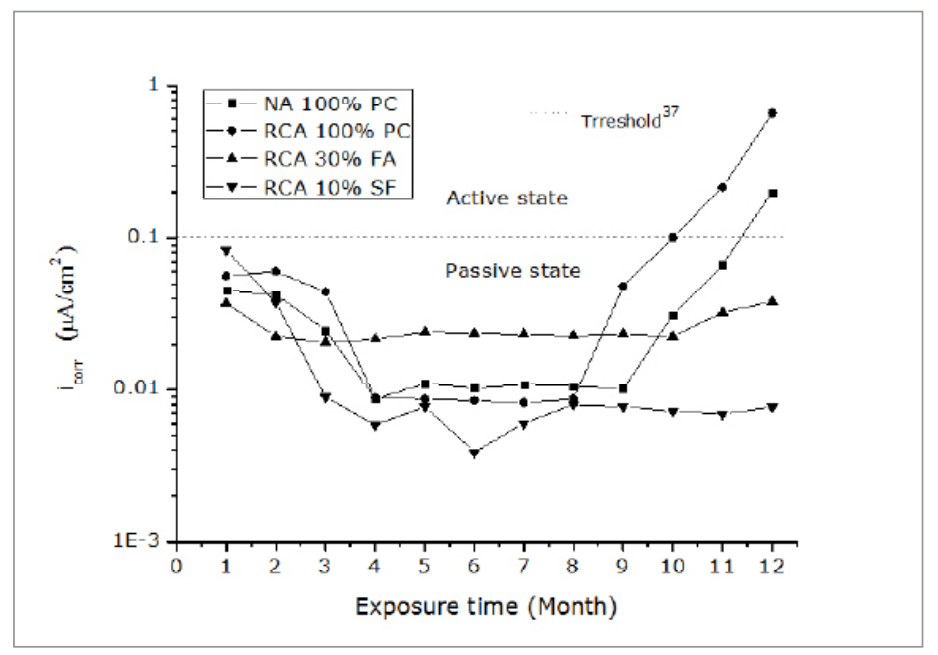

Figura 8. Variación de la densidad de corriente de corrosión en función del tiempo de exposición

Figure 9. Variation of corrosion current density as a function of exposure time

Above results indicate that although there is a significant difference of $\rho$ values among SCM systems, their corrosion resistance is maintained at the same magnitude level; this is explained because of the high content of $\mathrm{Al}_{2} \mathrm{O}_{3}(\cong 17 \%)$ in the FA that contributes to the formation of Friedel's salt or tri-calcium chloride-hydrate aluminates $\left(3 \mathrm{CaO} \cdot \mathrm{Al}_{2} \mathrm{O}_{3}\right.$. $\mathrm{CaCl}_{2} \cdot 10 \mathrm{H}_{2} \mathrm{O}$ ). Therefore, the addition of FA leads to a higher content of Friedel's salt in the cement matrix, and therefore to lower levels of free chlorides which are responsible of corrosion located on the reinforcement steel in this case. Above has been proven by means of the use of an XDR, as shown on Figure 9. Such compound was detected (highest peak of $2 \theta=11.18$ ) in each one of the mixes $(100 \%$ PC, replacing $P C$ by a $30 \%$ of $F A)$. Nevertheless, higher intensities are observed for the $F A$ mix than for the $100 \%$ PC mix.

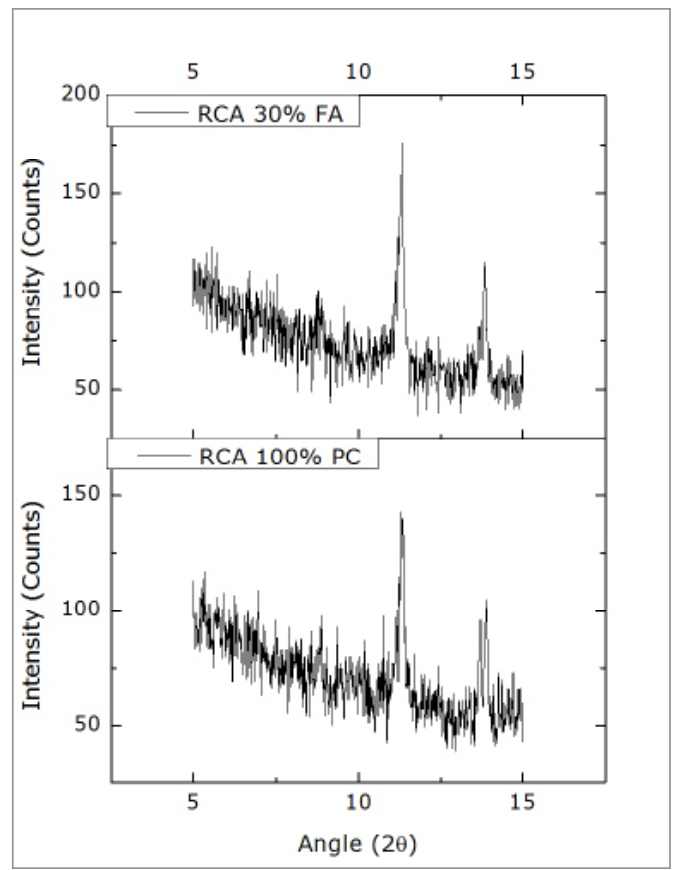

Figura 9. Patrón de rayos $X$ - Sal de Friedel Figure 9. $X$ Ray pattern of Friedel Salt 


\section{Resistance to ion chloride penetration}

Figure 10 shows the results of passing load in accordance with test procedure ASTM C1202. On one hand, the results indicate that the use of $100 \%$ RCA conditions concrete to decrease its ion chloride penetration resistance in about $30 \%$, in comparison to conventional concrete. On the other hand, it is observed that the use of FA and SF provide concrete with a great ability to inhibit ion chloride penetration, because the passing loads of mixes RCA 30\% FA and RCA 10\% SF are three and five times lower, respectively than in the mix RCA $100 \%$ PC. As per the criterion proposed by ASTM C1202 (Table 4), SCM-free mixes show a high ion chloride penetration because they exceed 4000 Coulombs, while the penetration capacity of SCM mixes is between 1000 and 2000 Coulombs which is considered low. These results agree with the ones reported by Ann et al. (2008).

The high ion chloride penetration resistance of SF mix is explained by the higher cement matrix densification, observed on Figure 11c (micro-graphy obtained by SEM), which substantially reduces porosity by restricting chloride permeability. Regarding the FA mix, in spite of the fact that its cement matrix has a similar compaction to the $100 \%$ PC mix (Figures 11a and 11b), the formation of Friedel's salt in a higher amount and the pores obstruction with non-reacting FA particles contribute to a lower ion chloride permeability.

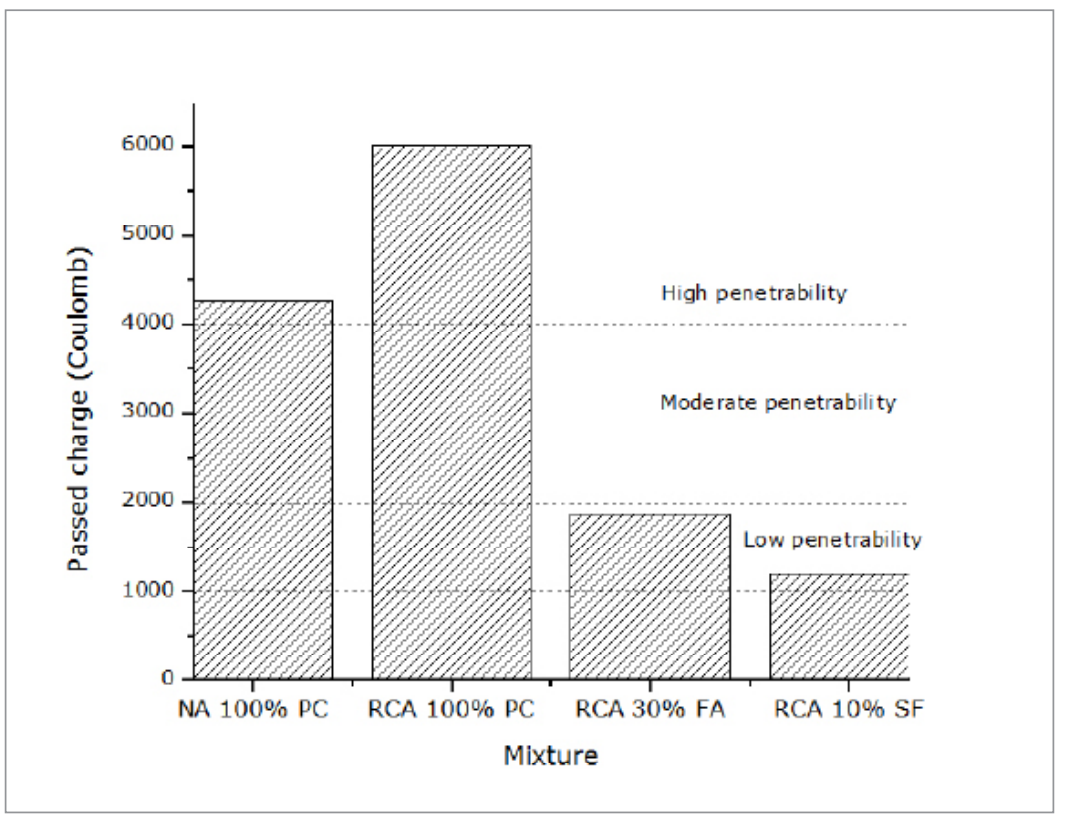

Figura 10. Resistencia a la penetración del ión cloruro

Figure 10. Resistance to chloride ion penetration 


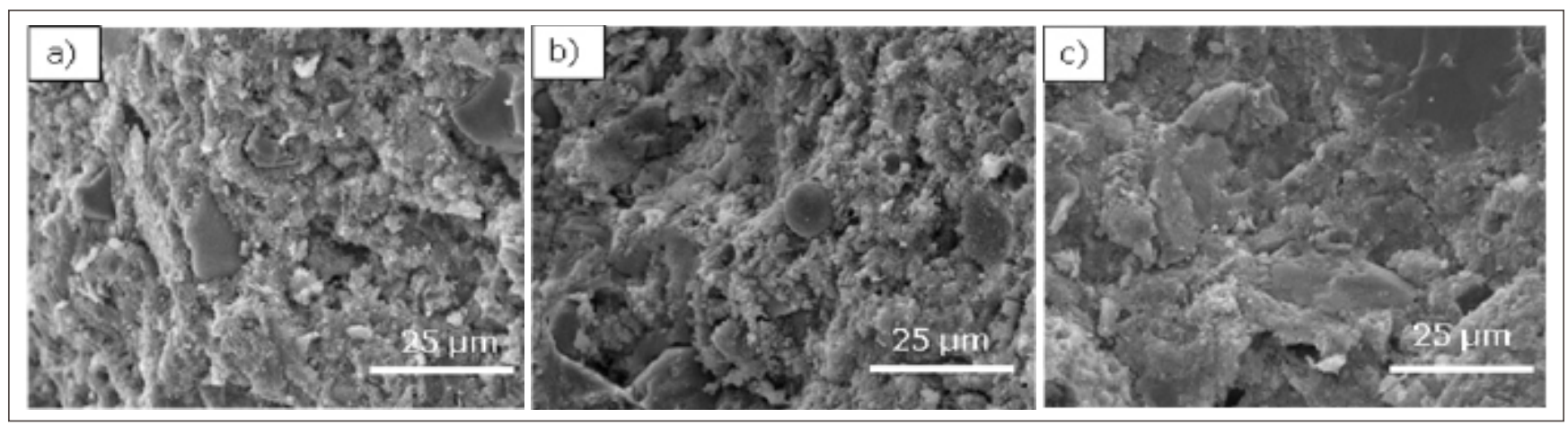

Figura 11. Microstructura de la matriz cementante a 90 días de hidratación: a) $100 \%$ PC, b) $70 \%$ PC - 30\% FA, c) $90 \%$ PC - 10\% SF

Figure 11. Cementing matrix microstructure to 90 days hydration: a) $100 \%$ PC, b) $70 \%$ PC - 30\% FA, c) $90 \%$ PC - $10 \% \mathrm{SF}$

\section{Conclusions}

Under the experimental conditions of this research, it is concluded that:

- The replacement of $100 \%$ of natural aggregate by RCA decreases concrete electric resistivity and the beginning time of reinforcement corrosion, besides increasing its corrosion speed.

- Flying ashes and silica fume double and quadruplicate, respectively the concrete electric resistivity; they delay the beginning of reinforcement corrosion and decrease its speed.

- Although the electric resistivity magnitude of concrete with silica fume is double than the one for concrete containing flying ashes, both corrosion resistances are similar due to a high content of $\mathrm{Al}_{2} \mathrm{O}_{3}$ in flying ashes, that contributes to the formation of Friedel's salt and reduces the ion chloride permeability.

- The results for total porosity and for PRPC indicate that concrete elaborated with RCA has a pore structure more open than conventional concrete. The use of $30 \% \mathrm{FA}$ and $10 \%$ HS leads to a decrease from three to five times, respectively, of the total load passing throughout concrete, which means a considerable increase of the ion chloride penetration resistance.

\section{Acknowledgements}

Authors wish to thank CONACYT for the economical contribution granted. Special thanks to the Autonomous University of Sinaloa, Research Center of Advanced Materials, SC and; to the Autonomous University of Nuevo León for the support in the samples characterization and results analysis. 


\section{Referencias/References}

Ajdukiewicz, A \& Kliszczewicz, A. (2002), 'Influence of recycled aggregates on mechanical properties of HS/HPC', Cement and Concrete Composites, vol. 24, no. 2 , pp. 269-279.

Andrade, C \& Alonso, C. (1996), 'Corrosion rate monitoring in the laboratory and on-site', Construction and Building Materials, vol. 10, no. 5, pp. 315328.

Ann K.Y, Moon H.Y, Kim Y.B \& Ryou, J. (2008), 'Durability of Recycled Aggregate Concrete using Pozzolanic Materials', Waste Management, vol. 28, no. 6, pp. 993-999.

Berndt, M.L. (2009), 'Properties of sustainable concrete containing fly ash, slag and recycled concrete aggregate', Construction and Buildings Materials, vol. 23, no. 7, pp. 2606-2613.

Dhir R.K, Jones M.R \& McCarthy M.J. (1993), 'Quatifying chloride-induced corrosion from half-cell potential', Cement and Concrete Research, vol. 23, no. 6, pp. 1443-1454.

Casuccio M, Torrijos M.C, Giaccio G \& Zerbino, R. (2008), 'Failure mechanism of recycled aggregate concrete', Construction and Buildings Materials, vol. 23, no. 7, pp. 1500-1506.

Chen H, Yen I, \& Chen, $\boldsymbol{K}$. (2003), 'Use of building rubbles as recycled aggregates', Cement and Concrete Research, vol. 33, no. 1, pp.125-133.

Corinaldesi, V \& Moriconi, G. (2009), 'Influence of mineral additions on the performance of $100 \%$ recycled aggregate concrete', Construction and Buildings Materials, vol. 23, no. 8, pp. 2869-2876.

Etxeberría M, Vazquez E \& Mari, A. (2007), 'Recycled aggregate concrete as structural material', Materials and Structures, vol. 40, no. 5, pp. 529-541.

Fajardo G, Valdez $\boldsymbol{P} \&$ Pacheco, J. (2009), 'Corrosion of steel rebar embedded in natural pozzolan based mortars exposed to chlorides', Construction and Building Materials, vol. 23, no. 2, pp.768-774.

Federal Highway Administration. (2002), 'Corrosion Costs and Preventative Strategies in the United States', Publication No. FHWA-RD-01-156.

González J.A, Ramírez E, Bautista A, Feliú, S. (1996), 'The behavior of pre-rusted steel in concrete', Cement and Concrete Research, vol. 26, no. 3, pp. 501-511.

Gómez, J.M.V. (2002), 'Porosity of recycled concrete with substitution of recycled concrete aggregate. An experimental study', Cement and Concrete Research, vol. 32, no. 8, pp. 1301-1311.

González B \& Martínez, F. (2008), 'Concretes with aggregates from demolition waste and silica fume'. Materials and mechanical properties', Building and Environment, vol. 43, no. 4, pp. 429-437.

Gowers, K.R \& Millard, S.G. (1993), 'On-site linear polarizaction resistancemapping of reinforced concrete structures', Corrosion Science, vol. 35, no. 5-8, pp. 1593-1600.

Katz, A. (2003), 'Properties of concrete made with recycled aggregate from partially hydrated old concrete', Cement and Concrete Research, vol. 33 no. 5, pp.703-711.

Kou S.C, Poon C.S \& Chan, D. (2008), 'Influence of fly ash as a cement addition on the hardened properties of recycled aggregate concrete', Materials and Structures, vol. 41, no. 7, pp. 1191-1201.

Mangat, P.S \& Molloy, B.T. (1992), 'Factors influencing chloride corrosion of reinforcement in concrete', Materials and Structures, vol. 25, no. 7, pp. 404-411.

Martínez, I \& Mendoza, C. (2006), 'Comportamiento mecánico de hormigón fabricado con agregados reciclados', Ingeniería Investigación y Tecnología, vol. 7, no. 3, pp. 151-164.

Padmini A.K, Ramamurthy K, \& Mathews, M.S. (2009), 'Influence of parent concrete on the properties of recycled aggregate concrete', Construction and Buildings Materials, vol. 23, no. 2, pp. 829-836.

Polder R, Andrade C, Elsener B, Vennesland O.E, Gulikers J, Weidert $\boldsymbol{R} \&$ Raupach, M. (2000), 'Test methods for on site measurement of resistivity of concrete', Materials and Structures, vol. 33, no. 10, pp. 603-611.

Poon C.S., Shui Z.H., Lam L, Fok H \& Kou, S.C. (2004), 'Influence of moisture states of natural and recycled aggregates on the slump and compressive strength of concrete', Cement and Concrete Research, vol. 34, no. 1, pp. 31-36.

Poon C.S, Shui Z.H \& Lam, L. (2004), 'Effect of microstructure of ITZ on compressive strength of concrete prepared with recycled aggregates', Construction and Buildings Materials, vol. 18, no. 6, pp. 461-468.

Rahal, $\boldsymbol{K}$. (2007), 'Mechanical properties of concrete with recycled coarse aggregate', Building and Environment, vol. 42, no. 1, pp. 407-415.

Stern, M \& Geary, A. (1957), 'Electrochemical Polarization', Journal of the electrochemical society, vol. 104, no. 56, pp. 56-63.

Sunderland, J.E \& Johnson, K.R. (1964). 'Shape factors for heat conduction through bodies with isothermal or convective boundary conditions', ASHRAE 71st Annual Meeting, Cleveland.

Tam V.W.Y, Gao X.F \& Tam, C.M. (2005), 'Microstructural analysis of recycled aggregate concrete produced from two-stage mixing approach', Cement and Concrete Research, vol. 35, no. 6, pp. 1195-1203.

Topçu, I \& Sengel, S. (2004), 'Properties of concretes produced with waste concrete aggregate', Cement and Concrete Research, vol. 34, no. 8, pp.13071312.

Torrents J.M, Roncero J \& Gettu, R. (1998), 'Utilization of impedance spectroscopy for studying the retarding effect of a superplasticizer on the setting of cement', Cement and Concrete Research, vol. 28, no. 9, pp. 1325-1333.

Tu T, Chen Y \& Hwang, C. (2006), 'Properties of HPC with recycled aggregates', Cement and Concrete Research, vol. 36, no. 5, pp. 943-950.

Tumidajski P.J, Shumacher A.S, Perron S, Gu P \& Beaudoin, J.J. (1996), 'On the relationship between porosity and electrical resistivity in cementitious systems', Cement and Concrete Research, vol. 26, no. 4, pp. 539-544.

Tumidajski, P.J. (2005), 'Relationship between resistivity, diffusivity and microstructural descriptors for mortars with silica fume', Cement and Concrete Research, vol. 35, no. 7, pp. 1262-1268. 